\title{
PENGARUH JUMLAH KUNJUNGAN WISATAWAN, PENERIMAAN PAJAK HOTEL, PAJAK RESTORAN TERHADAP PAD KABUPATEN SIKKA
}

\author{
Andri Waskita Aji \\ Rieshe \\ Program Studi Akuntansi, Fakultas Ekonomi \\ Universitas Sarjanawiyata Tamansiswa, Jalan Kusumanegara, \\ Yogyakarta 0274, Fax 557455 \\ Email korespondensi: rishelaga@gmail.com
}

\begin{abstract}
The purpose of this research is to find out how much influence: (1) the number of tourist visits to the Sikka Regency's original income; (2) hotel tax revenue from the Sikka Regency's original regional income; and (3) restaurant tax receipts from Sikka Regency's original revenue to Sikka Regency's original revenue both partially and simultaneously at the Sikka Regional Financial Management and Asset Management Service (DPPKAD). The data analysis technique used in this study is multiple linear regression analysis. The $\mathrm{F}$ test, $\mathrm{t}$ test and $\mathrm{R}^{2}$ test are processed using SPSS version 16.0. The results of data analysis with a significance of 0.05 indicate that the variable number of tourist visits and hotel tax revenue variables do not affect the original income of Sikka Regency 2016-2018. While the restaurant tax has a positive and significant effect on the original income of Sikka district 2016-2018. The results of the study simultaneously showed that the number of tourist visits, hotel tax receipts and restaurant tax receipts had a positive and significant effect on the genuine income of Sikka Regency. Independent and Dependent Variables affect 36\% while 64\% are explained independently by variables outside this research model.
\end{abstract}

Keywords: tourist visits, hotel tax, and restaurant tax, first income of region

\begin{abstract}
ABSTRAK
Tujuan penelitian ini adalah untuk mengetahui seberapa besar pengaruh: (1) jumlah kunjungan wisatawan terhadap pendapatan asli daerah Kabupaten Sikka; (2) penerimaan pajak hotel dari pendapatan asli daerah Kabupaten Sikka; dan (3) Penerimaan Pajak Restoran dari Pendapatan Asli Daerah Kabupaten Sikka terhadap Pendapatan Asli Daerah Kabupaten Sikka baik secara parsial maupun simultan di Dinas Pengelolaan Keuangan dan Aset Daerah (DPPKAD) Sikka. Teknik analisis data yang digunakan dalam penelitian ini adalah analisis regresi linier berganda. Uji $F$, uji t dan uji $\mathrm{R}^{2}$ diolah dengan menggunakan SPSS versi 16.0. Hasil analisis data dengan signifikansi 0,05 menunjukkan bahwa variabel jumlah kunjungan wisatawan dan variabel penerimaan pajak hotel tidak berpengaruh terhadap pendapatan asli daerah Kabupaten Sikka tahun 2016-2018. Sedangkan, pajak restoran berpengaruh positif dan signifikan terhadap pendapatan asli daerah kabupaten Sikka tahun 2016-2018. Hasil penelitian secara simultan menunjukkan bahwa jumlah kunjungan wisatawan, penerimaan pajak hotel dan penerimaan pajak restoran berpengaruh positif dan signifikan terhadap pendapatan asli Kabupaten Sikka. Variabel independen dan dependen mempengaruhi 36\% sedangkan 64\% dijelaskan secara independen oleh variabel di luar model penelitian ini.
\end{abstract}

Kata kunci: kunjungan wisatawan, pajak hotel, dan pajak restoran, pendapatan pertama daerah 


\section{PENDAHULUAN}

Pariwisata adalah sumber utama penggerak ekonomi di Negara berkembang seperti Indonesia. Indonesia adalah satu satu Negara yang memiliki kepulauan terbesar di dunia dengan didukung sumber daya alam yang beraneka ragam yang memiliki potensi jika diolah dan dikembangkan dengan baik dan yang tidak kalah menarik adalah keindahan wisata alamnya yang cukup potensial yang dapat diandalkan sebagai salah satu sumber penerimaan bagi setiap daerah. Menurut Undang-Undang Nomor 102009 tentang Kepariwisataan menyatakan bahwa wisata merupakan kegiatan perjalanan atau sebagian dari kegiatan wisata tersebut dilakukan secara sukarela serta bersifat sementara untuk menikmati obyek dan daya tarik wisata.

Pendapatan asli daerah (PAD) merupakan salah satu sumber pendapatan yang dapat mengembangkan serta mengoptimalkan semua potensi daerah yang digali dari dalam wilayah (Mulyadi (2011) dalam Sunarto \& Fatimah (2016)). Menurut Undang-undang No. 33 Tahun 2004, pendapatan asli daerah bersumber dari beberapa pendapatan diantaranya yaitu hasil pajak daerah, hasil retribusi daerah, hasil pengelolaan kekayaan daerah yang dipisahkan dan pendapatan asli daerah yang sah. Salah satu faktor yang dapat menunjang pertumbuhan pendapatan asli daerah adalah sektor pariwisata.

Salah satu daerah yang memiliki potensi Obyek wisata adalah Kabupaten Sikka. Kabupaten Sikka merupakan kabupaten yang terletak di Provinsi Nusa Tenggara Timur, Indonesia. Kabupaten ini memiliki sektor pariwisata yang strategis dan potensial untuk dikelola dan dikembangkan sebagai salah satu daerah industri pariwisata yang mampu menyerap tenaga kerja dan memberikan kontribusi bagi pendapatan asli daerah.

Pariwisata kabupaten Sikka yang terus berkembang akan menarik wisatawan untuk berkunjung ke setiap destinasi wisata yang ada. Jumlah wisatawan yang berkunjung ke suatu daerah sangat erat kaitannya terhadap pendapatan asli daerah itu sendiri. Semakin lama wisatawan tinggal di suatu daerah tujuan wisata, maka semakin banyak juga uang yang dibelanjakan di daerah tujuan wisata tersebut, paling sedikit untuk kebutuhan makan, minum, dan penginapan selama tinggal di daerah yang ditempati.

Tabel 1. Pertumbuhan Kunjungan Wisatawan ke Kabupaten Sikka 2014-2018

\begin{tabular}{cccc}
\hline Tahun & $\begin{array}{c}\text { Wisatawan } \\
\text { Mancanegara }\end{array}$ & Wisatawan Nusantara & Jumlah \\
\hline 2014 & 5.035 & 26.341 & 31.376 \\
2015 & 7.015 & 32.150 & 39.165 \\
2016 & 9.185 & 35.930 & 45.115 \\
2017 & 10.454 & 38.774 & 47.228 \\
2018 & 11.568 & 38.644 & 50.212 \\
\hline
\end{tabular}

Berdasarkan tabel di atas, jumlah kunjungan wisatawan di Kabupaten Sikka terus meningkat dari tahun 2014-2018. Dengan total kunjungan yang wisatawan yang terus mengalami peningkatan maka dapat mempengaruhi pendapatan asli daerah.

Tabel 1. Jumlah Pajak Hotel, Jumlah Pajak Restoran, Pendapatan Asli Daerah

\begin{tabular}{ccccc}
\hline No & Tahun & Jumlah Pajak Hotel & Jumlah Pajak Restoran & Jumlah PAD \\
\hline 1 & 2016 & 1.090 .886 .891 & 1.558 .015 .969 & 26.823 .993 .476 \\
2 & 2017 & 1.078 .212 .792 & 1.354 .246 .037 & 15.275 .300 .507 \\
3 & 2018 & 1.422 .490 .204 & 1.538 .000 .493 & 18.864 .510 .020 \\
\hline
\end{tabular}

Berdasarkan Tabel 2 di atas, jumlah pajak hotel, pajak restoran, jumlah Pendapatan asli daerah Pemerintah Kabupaten Sikka dari tahun 2016-2018 cenderung berfluktuasi. Hasil penelitian empiris ternyata menunjukan adanya kesenjangan antar variabel. Penelitian dari Suarjana et al. (2019) menjelaskan bahwa kunjungan wisatawan tidak berpengaruh terhadap pendapatan asli daerah. Syarifah (2018) menyatakan bahwa pajak hotel dan 
pajak restoran tidak memiliki hubungan yang signifikan terhadap pendapatan asli daerah.

Pada pemerintah kabupaten Sikka peningkatan jumlah kunjungan wisatawan terus mengalami peningkatan. Sedangkan pajak hotel, pajak restoran serta PAD mengalami fluktuasi hal ini perlu di cermati terutama hubungan antara variabel. Pada tahun 20142018, jumlah kunjungan wisatawan terus mengalami peningkatan namun pajak hotel, pajak restoran serta pendapatan asli daerah tidak terus mengalami peningkatan melainkan mengalami fluktuasi. Ada kalanya terjadi peningkatan jumlah kunjungan wisatawan, namun tidak di sertai dengan jumlah belanja/pengeluaran yang cukup tinggi, hal ini kurang memberikan dampak bagi pertumbuhan ekonomi. Selain itu, terdapat ketidakkonsistenan hasil pada beberapa variabel penelitian terdahulu, terutama relevansi antara kunjungan wisatawan, penerimaan pajak hotel dan restoran terhadap PAD.

Berdasarkan uraian latar belakang di atas, maka penulis melakukan penelitian yang berjudul "Pengaruh Jumlah Kunjungan Wisatawan, Penerimaan Pajak Hotel dan Penerimaan Pajak Restoran terhadap Pendapatan Asli Daerah Kabupaten Sikka”.

\section{KAJIAN LITERATUR DAN PENGEMBANGAN HIPOTESIS}

\section{Jumlah Kunjungan Wisatawan}

Menurut Undang-Undang Nomor 10

2009 Tentang Kepariwisataan Pasal 1 menyebutkan "Wisata merupakan kegiatan perjalanan yang dilakukan seseorang atau sekelompok orang dengan mengunjungi tempat tertentu untuk tujuan rekreasi, pengembangan pribadi, maupun mempelajari keunikan daya tarik wisata yang dikunjungi untuk waktu yang sementara”. Menurut Undang-Undang Nomor 10 tahun 2009, wisatawan adalah orang-orang yang melakukan kegiatan wisata. Sedangkan pengertian wisatawan menurut (Instruksi Presiden Indonesia Nomor 9 Tahun 1969 Pasal 1 ayat 1 adalah sebagai berikut: "Wisatawan (tourist) adalah setiap orang yang berpergian dari tempat tinggalnya untuk berkunjung ke tempat lain dengan menikmati perjalanan dan kunjungan itu". Wisatawan adalah orang-orang yang melakukan kegiatan wisata (Undang-
Undang nomor 10 tahun 2009). Jadi, jumlah kunjungan wisatawan adalah semuaorang yang melakukan perjalanan wisata dari tempat tinggalnya untuk berkunjung ke tempat lain dengan tujuan menikmati destinasi wisata.

Menurut Nasrul (2010) dalam Swantara \& Darsana (2017), jumlah kunjungan wisatawan memiliki pengaruh positif dan signifikan terhadap pendapatan asli daerah (PAD). Semakin lama wisatawan tinggal dan menginap dalam setiap kunjungan obyek wisata yang ada, maka semakin bertambah pula pengeluaran yang akan dibelanjakan di daerah destinasi wisata tersebut. Selanjutnya pengeluaran tersebut akan menjadi salah satu sumber pendapatan daerah.

Dari hasil penelitian Suastika \& Yasa (2017), Pertiwi (2014), dan Wijaya dan Sudiana (2016) menyatakan bahwa Jumlah kunjungan wisatawan berpengaruh positif terhadap Pendapatan Asli Daerah. Berdasarkan uraian tersebut maka dapat dijelaskan hipotesis sebagai berikut:

H1: Jumlah Kunjungan Wisatawan berpengaruh positif terhadap Pendapatan Asli Daerah (PAD).

\section{Penerimaan Pajak Hotel}

Definisi pajak hotel sebagaimana dijelaskan berdasarkan Peraturan Derah Kabupaten Sikka Nomor 10 Tahun 2011 tentang pajak daerah menyebutkan Hotel adalah fasilitas penyedia jasa penginapan termasuk jasa lainnya dengan di pungut bayaran, yang mencangkup hotel, losmen, gubuk pariwisata, pesanggarahan, rumah penginapan, dan sejenisnya rumah kos boga/catering. Sedangkan pajak restoran adalah pajak atas pelayanan yang disediakan oleh Irestoran, rumah makan, kafetaria, kantin, warung bar, dan dengan jumlah kamar lebih dari sepuluh sejenisnya termasuk jasa boga atau catering.

Salah satu pajak daerah yang potensinya semakin berkembang seiring dengan semakin diperhatikannya sektor jasa dalam kebijakan pembangunan yang menyebabkan bisnis perdagangan, jasa dan pariwisata berkembang adalah pajak hotel dalam Zulhuda (2017).

Dari hasil penelitian yang dilakukan Pertiwi (2014) dan Wijaya \& Sudiana (2016) menyatakan bahwa Pajak Hotel 
berpengaruh signifikan terhadap pendapatan asli daerah. Berdasarkan uraian tersebur maka dapat dijelaskan hipotesis sebagai berikut:

H2: Pajak Hotel berpengaruh positif terhadap Pendapatan Asli Daerah (PAD).

\section{Penerimaan Pajak Restoran}

Berdasarkan Peraturan Derah Kabupaten Sikka Nomor 10 Tahun 2011 tentang pajak daerah Restoran adalah fasilitas penyedia makanan dan minuman dengan dipungut bayaran, yang mencakup rumah makan, kaferia, kantin, warung, bar, dan sejenisnya termasuk jasa. Berdasarkan Peraturan Daerah Nomor 7 Tahun 2010 Pasal 12, dasar pengenaan pajak restoran adalah jumlah penerimaan yang diterima restoran dengan penetapan tarif sebesar sepuluh persen (10\%). Hal ini dapat memberikan keleluasaan kepada pemerintah dalam menetapkan besarnya tarif pajak restoran.

Dari hasil penelitian yang dilakukan oleh Swantara \& Darsana (2017) dan Suarjana et al. (2019) menyatakan bahwa pajak restoran berpengaruh positif terhadap pendapatan asli daerah. Berdasarkan uraian tersebut, maka dapat dijelaskan hipotesis sebagai berikut:

H3: Pajak Restoran berpengaruh terhadap Pendapatan Asli Daerah (PAD).

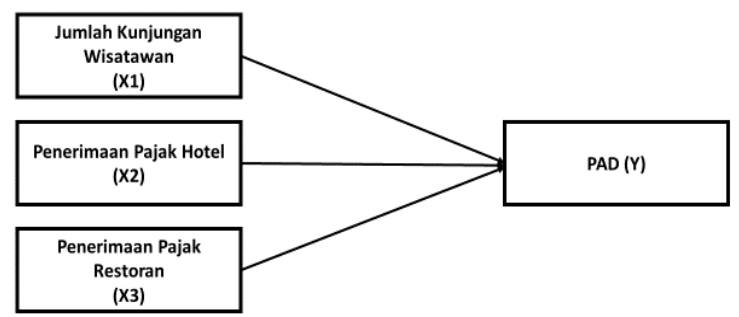

Gambar 1. Model Penelitian

\section{METODE}

Data yang digunakan dalam penelitian ini adalah data sekunder. Data sekunder adalah data yang diperoleh oleh peneliti secara tidak langsung, biasanya berupa catatan, dokumen, buku, dan laporan. Jenis penelitian ini adalah penelitian kuantitatif. Menurut Sugiyono (2010) dalam Kesek (2013), penelitian kuantitatif adalah suatu proses untuk menemukan pengetahuan yang menggunakan data berupa angka sebagai alat menganalisis keterangan mengenai apa yang ingin diketahui.

Sampel dalam penelitian ini adalah laporan jumlah kunjungan wisatawan, penerimaan pajak hotel, penerimaan pajak restoran dan pendapatan asli daerah (PAD) yang ada di seluruh kabupaten Sikka mulai dari tahun 2016-2018.

Sumber data dalam penelitian ini adalah data sekunder. Menurut Sugiyono (2017:137), data sekunder adalah sumber data yang tidak langsung memberikan data kepada pengumpul data. Dalam penelitian ini, data sekunder diambil dari DPPKAD dan Dinas Kepariwisataan dan Kebudayaan Kabupaten Sikka.

Teknik analisis datayang digunakan dalam penelitian ini adalah analisis regresi linier berganda. Tahap pertama yaitu melalui pengujian asumsi klasik yang terdiri dari uji normslitas, uji multikoliniearitas, uji heteroskedasitas, dan uji autokorelasi. Tahap kedua yaitu analisis regresi linier berganda serta tahap terakhir yaitu uji signifikansi yang terbagi atas uji $\mathrm{F}$ atau uji hubungan bersama antara semua variabel independen dan dipenden, uji t atau uji hubungan per variabel independen terhadap variabel dependen, dan uji koefisien determinasi $\left(\mathrm{R}^{2}\right)$.

\section{HASIL DAN PEMBAHASAN}

\section{Statistik Deskriptif}

Statistik deskriptif adalah pengolahan data untuk tujuan untuk mendeskripsikan dan memberi gambaran pada suatu data yang dilihat dari nilai rata-rata, standar deviasi, varian, maksimum, sum, range, kurtosis, dan skewness (kemencengan distribusi). Hasil perhitungan dari statistik deskriptif dari masing-masing variabel sebagai berikut: 
Tabel 3. Statistik Deskriptif

\begin{tabular}{lccccc}
\hline & N & Minimum & Maximum & Mean & Std. Deviation \\
\hline KW & 36 & 2512 & 5946 & 4042.75 & 906.715 \\
PH & 36 & 2427697 & 497638367 & 99766385.75 & 82952615.753 \\
PR & 36 & 42103835 & 335750996 & 123618402.75 & 65300398.510 \\
PAD & 36 & 319815086 & 5339381644 & 1651023434.86 & 1137512599.047 \\
Valid N & 36 & & & & \\
listwise & & & & & \\
\hline
\end{tabular}

Hasil uji deskriptif diatas menunjukan bahwa variabel jumlah kunjungan wisatawan memilki nilai minimum dari seluruh data sampel yaitu 2.512 orang pada bulan Februari tahun 2016, nilai maksimum atau nilai data tertinggi dari seluruh data sampel sebesar 5.946 orang pada bulan Agustus 2017, Nilai mean atau nilai rata-rata pada jumlah kunjungan dari seluruh jumlah data sampel yaitu sebesar 4.042,75 orang. Dan nilai standar deviasi pada jumlah kunjungan wisatawan sebesar 906.715 orang. Variabel Penerimaan pajak restoran memilki nilai minimum yang dimiliki pada pajak hotel dari seluruh sampel yang ada sebesar Rp. 24.276.497 pada bulan April 2016, nilai maximum atau nilai data tertinggi dari pajak hotel yang ditunjukan dari seluruh sampel yaitu sebesar Rp. 497.638.367 pada bulan Desember tahun 2016, Nilai mean atau nilai rata-rata pajak hotel dari seluruh jumlah data sampel yaitu sebesar Rp 99.766.385,75, dan nilai standar deviasi pada pajak hotel sebesar $\mathrm{Rp}$ 82.952.615,753. Variabel Penerimaan Pajak Restoran memiliki nilai minimum yang dimiliki pajak restoran dari seluruh sampel yang ada sebesar Rp 42.103.835 pada bulan Juni tahun 2017, sedangkan nilai maksimum atau nilai data tertinggi dari pajak restoran yang ditunjukan dari seluruh sampel yaitu sebesar Rp 335.750.996 pada bulan desember 2016, nilai mean atau nilai rata-rata pajak hotel dari seluruh jumlah data sampel yaitu sebesar Rp 123.618.402,75, dan nilai standar deviasi pada pajak hotel sebesar Rp 65.300.398,510.

Dan variabel terikat, pendapatan asli daerah memiliki nilai minimum yang dimiliki pada pendapatan asli daerah dari seluruh sampel yang ada sebesar Rp 319.815.086 pada bulan januari tahun 2016, sedangkan nilai maximum atau nilai data tertinggi dari pajak restoran yang ditunjukan dari seluruh sampel yaitu sebesar Rp 53.393.881.644 pada bulan desember 2017, nilai mean atau nilai rata- rata pendapatan asli daerah dari seluruh jumlah data sampel yaitu sebesar Rp1.651.023.434,86, dan nilai standar deviasi pada pendapatan asli daerah sebesar Rp1.137.512.599,047.

\section{Uji Asumsi Klasik}

Dari hasil pengujian uji normalitas diperoleh data bahwa nilai Asymp. Sig. (2tailed) sebesar 0,24. Dari hasil ini menunjukan bahwa signifikansi lebih besar dari 0,05, sehingga data terdistribusi secara normal. Berdasarkan uji multikolinieritas menunjukan bahwa variabel jumlah kunjungan wisatawan, penerimaan pajak hotel dan penerimaan pajak restoran memiliki nilai VIF $<10$, dapat disimpulkan bahwa tidak terjadi gejala multikolinieritas antar variabel independen. Berdasarkan uji heteroskedasitas menunjukan bahwa variabel jumlah kunjungan wisatawan, penerimaan pajak hotel dan penerimaan pajak restoran tidak signifikan pada 0,05 yang artinya tidak terjadi heteroskedastistas. Dan uji autokorelasi diketahui bahwa nilai DW sebesar 1,497 lebih kecil dari batas atas (dU) 1,6539 dan 4-dU lebih besar dari nilai Durbin Watson. Menurut kriteria keputusan Durbin Watson nilai $\mathrm{DU}>\mathrm{DW}>4$-DU, artinya dalam variabel ini ada autokorelasi positif tetapi lemah, dan akan lebih baik jika ada perbaikan.

\section{Analisis Regresi Berganda}

Uji Koefisien Koefisien Determinasi (R2)

Tabel 4. Hasil Uji Koefisien Determinasi

\begin{tabular}{|c|c|c|c|c|}
\hline Model & $\mathbf{R}$ & R-Square & $\begin{array}{c}\text { Adjusted R } \\
\text { Square }\end{array}$ & $\begin{array}{c}\text { Std. Error of the } \\
\text { Estimate }\end{array}$ \\
\hline 1 & $.644^{\mathrm{a}}$ & .415 & .360 & 910121886.237 \\
\hline
\end{tabular}


Berdasarkan hasil uji koefisien Determinasi $\left(\mathrm{R}^{2}\right)$ di atas menunjukan bahwa nilai koefisien determinasi yang dinyatakan dalam Adjusted R Square (R2) sebesar 0,360 atau $36 \%$. Hal ini berarti $36 \%$ variasi atau pendapatan asli daerah dapat dijelaskan oleh variasi jumlah kunjungan wisatawan, penerimaan pajak hotel, dan penerimaan pajak restoran. Sedangkan 64\% dijelaskan oleh independen oleh variabel diluar model penelitian ini.

Uji Parsial (t)

\begin{tabular}{|c|c|c|c|c|c|c|}
\hline \multirow{2}{*}{\multicolumn{2}{|c|}{ Model }} & \multicolumn{2}{|c|}{ Unstandardized Coefficients } & \multirow{2}{*}{$\begin{array}{c}\begin{array}{c}\text { Standardized } \\
\text { Coefficients }\end{array} \\
\text { Beta } \\
\end{array}$} & \multirow[t]{2}{*}{$\mathbf{T}$} & \multirow[t]{2}{*}{ Sig } \\
\hline & & B & Std. Error & & & \\
\hline 1 & (Constant) & $\begin{array}{c}81109181 . \\
419\end{array}$ & $\begin{array}{c}787897222 \\
.087\end{array}$ & & 103 & .919 \\
\hline & KW & 64857.177 & $\begin{array}{c}173225.07 \\
7\end{array}$ & .052 & .374 & .711 \\
\hline & $\begin{array}{l}\mathrm{PH} \\
\mathrm{PR}\end{array}$ & $\begin{array}{l}3.474 \\
7.775\end{array}$ & $\begin{array}{l}2.499 \\
3.157\end{array}$ & $\begin{array}{l}.253 \\
.446\end{array}$ & $\begin{array}{l}1.390 \\
2.463\end{array}$ & $\begin{array}{l}.174 \\
.019\end{array}$ \\
\hline
\end{tabular}

Berdasarkan Tabel 4, maka dapat disimpulkan:

\section{Pengaruh Jumlah Kunjungan Wisatawan}

Berdasarkan hasil uji statistik t, diperoleh nilai t hitung sebesar 0,374 dan nilai signifikan sebesar 0,711 jika dilihat dari perbandingan $t$ hitung dengan $\mathrm{t}$ tabel ( $\mathrm{t}$ hitung $<\mathrm{t}$ tabel) nilai $\mathrm{t}$ hitung diketahui kurang dari nilai $t$ tabel $(0,374$ $<1,69236)$ dan nilai signifikan lebih besar dari $0,05(0,711>0,05)$. Jadi, dapat disimpulkan jumlah kunjungan wisatawan tidak berpengaruh terhadap pendapatan asli daerah (PAD).

\section{Pengaruh Penerimaan Pajak Hotel terhadap PAD}

Berdasarkan hasil uji statistik t, diperoleh nilai t hitung sebesar 1,390 dan nilai signifikan sebesar 0,174 . Nilai t hitung sebesar 1,390 lebih kecil dari nilai t tabel sebesar 1,69236 (1,390 <

1,69236). Dan nilai signifikan lebih besar dari $0,05(0,174>0,05)$, jadi dapat disimpulkan bahwa penerimaan pajak hotel tidak berpengaruh terhadap pendapatan asli daerah (PAD).

\section{Pengaruh Penerimaan Pajak Restoran terhadap PAD}

Berdasarkan hasil uji statistik t, diperoleh nilai t hitung sebesar 2,463 dan nilai signifikan sebesar 0,019. Nilai t hitung sebesar 2,463 lebih besar dari nilai t tabel sebesar 1,69236 (2,463 > 1,69236). Dan nilai signifikan lebih kecil dari $0,05(0,019<0,05)$, jadi dapat disimpulkan bahwa penerimaan pajak restoran berpengaruh signifikan terhadap pendapatan asli daerah (PAD).

\section{Uji Simultan (F)}

Tabel 6. Tabel Uji Simultan

\begin{tabular}{|c|c|c|c|c|c|c|}
\hline \multicolumn{7}{|c|}{ ANOVA $^{b}$} \\
\hline & Model & Sum of Squares & Df & Mean Square & $\mathbf{F}$ & Sig \\
\hline \multirow[t]{3}{*}{1} & Regression & $\begin{array}{c}1878142282484781 \\
5000.000\end{array}$ & 3 & $\begin{array}{c}6260474274949 \\
271600.000\end{array}$ & 7.558 & $.001^{\mathrm{a}}$ \\
\hline & Residual & $\begin{array}{c}2650629912982611 \\
0000.000\end{array}$ & 32 & $\begin{array}{c}8283218478070 \\
65980.000\end{array}$ & & \\
\hline & Total & $\begin{array}{c}4528772195467393 \\
0000.000\end{array}$ & 35 & & & \\
\hline
\end{tabular}

Hasil uji statistik F dari tabel 6 menunjukan P-Value sebesar 0,001 lebih kecil 0,05 dan diketahui nilai $\mathrm{F}$ hitung sebesar 7.558. Nilai $F$ tabel pada taraf signifikan $5 \%$ dengan Df $(3 ; 36)$ adalah sebesar 2,89. Jadi, nilai $F$ hitung $>$ F tabel. (7.558 $>2,89)$. Sehingga dapat disimpulkan bahwa hipotesis tidak dapat di tolak yang artinya jumlah kunjungan wisatawan, penerimaan pajak hotel, dan penerimaan pajak restoran secara simultan mempunyai pengaruh signifikan terhadap pendapatan asli daerah (PAD).

\section{SIMPULAN DAN SARAN}

Penelitian ini merupakan penelitian kuantitatif dengan sumber data sekunder. Variabel independen yang digunakan dalam penelitian ini adalah Jumlah Kunjungan Wisatawan, Penerimaan Pajak Hotel, dan Penerimaan Pajak Restoran serta variabel 
dependennya adalah Pendapatan Asli Daerah. Populasi dalam penelitian ini adalah data jumlah kunjungan wisatawan, penerimaan pajak hotel, dan penerimaan pajak restoran serta pendapatan asli daerah.

1. Jumlah kunjungan wisatawan (X1) tidak berpengaruh terhadap pendapatan asli daerah (PAD). Karena banyaknya wisatawan yang berkunjung ke obyek wisata namun obyek wisata tertentu misalnya pemanfaatan Pusat Jajanan dan Cinderamata (PJC), sewa panggung dan lokasi, parkir PJC dan sewa Billboard yang dikelolah oleh pemerintah untuk sementara ini, sedangkan obyek wisata yang ada dikelola oleh pihak swasta atau masyarakat setempat sehingga pendapatan daerah di sektor wisata belum mengalami pertumbuhan. Karena itu banyak atau tidaknya wisatawan yang berkunjung belum mempengaruhi pendapatan asli kabupaten Sikka.

2. Penerimaan pajak hotel tidak berpengaruh terhadap pendapatan asli daerah (PAD). Hal ini juga dikarenakan di Kabupaten Sikka belum banyak hotel yang dibangun sehingga penerimaan pajak hotel belum mempunyai pengaruh dan belum mempunyai kontribusi yang berarti terhadap pendapatan daerah kabupaten Sikka.

3. Penerimaan pajak restoran (X3) berpengaruh positif dan signifikan terhadap pendapatan asli daerah (PAD). Karena semakin banyaknya restoran di Kabupaten Sikka maka pajak restoran meningkat sehingga pendapatan asli daerah akan meningkat.

4. Jumlah kunjungan wisatawan (X1), Penerimaan Pajak Hotel (X3), Penerimaan Pajak Restoran (X3) secara simultan atau secara bersama-sama berpengaruh terhadap pendapatan asli daerah (PAD). Pemerintah Kabupaten Sikka diharapkan dapat lebih mengoptimalkan dan meningkatkan penerimaan pajak daerah sehingga pendapatan asli daerah pun meningkat.

\section{Saran}

Adapun saran yang berkaitan dengan penelitian ini dan diharapkan dapat menjadi pertimbangan bagi berbagai pihak terkait sebagai berikut:
1. Kepada pemerintah Dinas Pariwisata Kabupaten Sikka dapat diharapkan memberikan kebijakan peraturan daerah dalam pengelolahan setiap objek wisata yang ada, sexhingga objek wisata yang dikelola pemerintah maupun perorangan dapat terkontrol dengan baik oleh Dinas Pariwisata Kabupaten Sikka.

2. Pemerintah sebaiknya meningkatkan program melalui promosi pariwisata dan meningkatkan kualitas sarana prasaran pada tiap objek wisata yang ada di Kabupaten Sikka sehingga dapat menarik minat wisatawan untuk berkunjung. Hal ini akan berdampak pada pertumbuhan pendapatan asli daerah.

3. Pemerintah harus sering melakukan sosialisasi terhadap wajib pajak dalam hal ini yang dimaksudkan adalah wajib pajak Restoran, wajib pajak Hotel agar wajib pajak mengetahui hak dan kewajiban yang dimliki. Sosialisasi ini juga memberikan pengetahuan bagi masyarakat akan pentingnya membayar pajak.

4. Peneliti selanjutnya dapat menambah jumah sampel yang lebih banyak agar hasil penelitian yang dihasilkan lebih baik.

\section{REFERENSI}

Gde Mantra Suarjana, A. A., Indah Kusuma Dewi, N., \& Mei Wahyuni, L. (2019). Pengaruh Kunjungan Wisatawan, Pajak Hotel dan Restoran terhadap Pendapatan Asli Daerah Pemerintah Kabupaten Gianyar-Bali. Jurnal Bisnis dan Kewirausahaan, 15(1), 39.

Instruksi Presiden Indonesia Nomor 9 Tahun 1969.

Kesek, F. (2013). Efektivitas Dan Kontribusi Penerimaan Pajak Parkir Terhadap Pendapatan Asli Daerah Kota Manado. Jurnal Riset Ekonomi, Manajemen, Bisnis dan Akuntansi, 1(4), 1922-1933.

Peraturan Daerah Kabupaten Sikka Nomor 10 Tahun 2011.

Pertiwi, N. L. G. A. (2014). Pengaruh Kunjungan Wisatawan, Retribusi Obyek Wisata dan PHR Terhadap PAD 
Kabupaten Gianyar. E-Jurnal EP Unud, 3(3), 115-123.

Rahmi, Syarifah. (2018). Pengaruh Jumlah Kunjungan Wisatawan, Restoran terhadap Pendapatan Asli Daerah.

Suastika, I. G. Y., \& Yasa, I. N. M. (2017). Pengaruh Jumlah Kunjungan Wisatawan, Lama Tinggal Wisatawan, dan Tingkat Hunian Hotel Terhadap Pendapatan Asli Daerah dan Kesejahteraan Masyarakat Pada Kabupaten/Kota di Provinsi Bali. EJurnal EP UNUD, 6(7), 1332-1363.

Sudiana, I. B. A. B. W. I. K. (2016). Pengaruh Jumlah Kunjungan Wisatawan, Penerimaan Pajak Hotel, Restoran dan Pendapatan Retribusi Obyek Wisata terhadap Pendapatan Asli Daerah di Kabupaten Bangli Periode 2009-2015. E-Jurnal EP Unud, 5(12), 1384-1407.

Sugiyono. (2017). Metode Penelitian Kuantitatif, Kualitatif, dan R\&D. Bandung: Alfabeta.

Sunarto, \& Fatimah, R. D. A. N. (2016). Pengaruh Penerimaan Retribusi Dan Penetapan Tarif Obyek Wisata Terhadap Pendapatan Asli Daerah Kabupaten Gunung Kidul Tahun 2013-2015. Jurnal Akuntansi, 4(2).

Swantara, I. K. B. P., \& Darsana, I. B. (2017). Pengaruh Kunjungan Wisatawan, Pendapatan PHR, dan Penerimaan Retribusi Obyek Wisata terhadap PAD Kabupaten Gianyar. EJurnal EP Unud, 6(12), 2551-2582.

Undang-undang No 33 Tahun 2004.

Undang-Undang Nomor 102009 Tentang Kepariwisataan.

Zulhuda, F. (2017). Kontribusi Pajak Hotel terhadap Pendapatan Asli Daerah Kota Semarang. Retrieved from http://www.fisip.undip.ac.id/Email. 